\title{
KEBIJAKAN PENDIDIKAN DI ERA OTONOMI DAERAH DALAM MEMPERKUAT KARAKTER BANGSA
}

\author{
H. M. Said Saggaf \\ Program Pascasarjana STIA PRIMA Sengkang
}

\begin{abstract}
ABSTRAK
Karakter bangsa merupakan sebuah identitas sebuah Negara, dengan identitas tersebut, mampu menjadi penilaian bagi Negara di dunia. Oleh karena itu, di era otonomi daerah sekarang ini dibutuhkan sebuah kebijakan pemerintah dalam upaya memperkuat karakter bangsa yang bermartabat di mata dunia. Hal ini sesuai dengan kebijakan nasional pembangunan karakter bangsa yang disusun sebagai amanat Rencanan Pembangunan Jangka Panjang Nasional Tahun 2010-2025. Adapun strategi dalam memperkuat karakter bangsa adalah dengan menjadikan kerjasama dapat berjalan dengan baik dan mencapai tujuan yang telah disepakati. Hal itu dapat dimulai dengan saling terbuka, saling mengerti, dan saling menghargai. Setelah kerjasama dapat dilakukan, maka langkah selanjutnya adalah koordinasi dan evaluasi.
\end{abstract}

Kata Kunci: Kebijakan Pendidikan, Otonomi Daerah, Karakter Bangsa.

\section{PENDAHULUAN}

Pendidikan merupakan suatu usaha yang sadar dan sistematis dalam mengembangkan potensi peserta didik. Sedangkan budaya diartikan keseluruhan sistem berpikir, nilai, moral, norma, dan keyakinan (belief) manusia yang dihasilkan masyarakat. Karakter merupakan watak, tabiat, akhlak, atau kepribadian seseorang yang terbentuk dari hasil internalisasi berbagai kebajikan (virtues) yang diyakini dan digunakan sebagai landasan untuk cara pandang, berpikir, bersikap, dan bertindak. Oleh karena itu, Pendidikan Karakter Bangsa disimpulkan sebagai suatu usaha sadar dan sistematis dalam mengembangkan potensi peserta didik agar mampu melakukan proses internalisasi, menghayati nilai-nilai karakter yang baik menjadi kepribadian mereka dalam bergaul di masyarakat, dan mengembangkan kehidupan masyarakat yang lebih sejahtera, serta mengembangkan kehidupan bangsa yang bermartabat. Sebagaimana yang telah diatur dalam
Peraturan-peraturan yang dimaksud antara lain UU No. 20 tahun 2003 tentang Sistem pendidikan nasional dan Peraturan Pemerintah tentang Standar Nasional Pendidikan.

Upaya dalam memaksimalkan pendidikan di Indonesia maka pemerintah mengambil sebuah kebijakan nasional sebagaimana telah diatur dalam undangundang No. 22 Tahun 1999 Jo UU Nomor 32 Tahun 2004, urusan pendidikan diserahkan kepada daerah. Hal ini berarti bahwa daerah mempunyai wewenang yang penuh di dalam mengatur dan mengelola pendidikan yang ada di daerahnya, baik pendidikan dasar maupun pendidikan tinggi (Tilaar, 2012: 64).

Yang menjadi masalah dewasa ini ialah Dampak globalisasi yang terjadi saat ini membawa masyarakat Indonesia melupakan pendidikan karakter bangsa. Pada hal, pendidikan karakter merupakan suatu pondasi bangsa yang sangat penting dan perlu ditanamkan sejak kini kepada anak-anak (Muslich, 2011: 1). Pembangunan karakter merupakan 
kebutuhan asasi dalam proses berbangsa dan bernegara. Sejak awal kemerdekaan, bangsa Indonesia sudah bertekad untuk menjadikan pembangunan karakter bangsa sebagai bagian penting dan tidak terpisahkan dari pembangunan nasional. Senada dengan itu, Garin Nugroho, ketika memberikan orasi budaya pertama "Pendidikan Karakter Kunci Kemajuan Bangsa" di Jakarta, sabtu (3/3/2010), mengatakan bahwa sampai saat ini dunia pendidikan Indonesia di nilai belum mendorong pembangunan karakter bangsa. Hal ini disebabkan oleh ukuran-ukuran dalam pendidikan tidak dikembalikan kepada karakter peserta didik, tapi dikembalikan kepada pasar. "Pendidikan nasional belum mampu mencerahkan bangsa ini. Pendidikan kita kehilangan nilai-nilai luhur kemanusiaan, padahal pendidikan seharusnya memberikan pencerahan nilai-nilai luhur itu," katanya, lebih lanjut ia mengemukakan bahwa pendidikan nasional kini telah kehilangan rohnya lantaran tunduk terhadap pasar bukan pencerahan terhadap peserta didik." Pasar tanpa karakter akan hancur dan akan menghilangkan aspek-aspek manusia dan kemanusiaan, karena kehilangan karakter itu sendiri," ucapnya (Muslich, 2011: 1).

$$
\text { Fenomena tersebut seolah }
$$

memantapkan hasil survey PERC (Political and Economic Risk Consultasy) dan UNDP (United Nations Development Program). PERC menyebutkan bahwa system pendidikan di Indonesia menempati posisi terburuk di kawasan asia (dari 12 negara yang di survey oleh PERC). Korea Selatan dinilai memiliki system pendidikan terbaik, di susul singapura, jepang, Taiwan, India, Cina dan Malaysia. Indonesia menduduki urutan ke 12 setingkat di bawah Vietnam (Kompas, 5/9/2001). Sementara itu, laporan UNDP tahun 2004 dan 2005 menyatakan bahwa Indeks Pembangunan Manusia (IPM) di Indonesia pun tetap terpuruk tahun 2004 Indonesia menempati urutan 111 dari 175; sedangkan tahun 2005 IPM Indonesia berada pada urutan ke 110 dari 177 negara. Pada tahun 2004 IPM Indonesia menempati posisi di bawah Negara-negara miskin seperti Kirgistan (110), Equatorial Guinea (109), dan Algeria (108). Data tersebut terasa lebih menyakitkan jika posisi Indonesia dibandingkan dengan beberapa Negara anggota ASEAN lainnya; singapura (25) Brunai Darussalam (33) Malaysia (58), Thailand (76), dan Filiphina (83). Indonesia hanya satu tingkat di atas Vietnam (112) dan lebih baik dari Kamboja (130), dan Laos (132).

\begin{tabular}{rrrr}
\multicolumn{2}{c}{ Menyadari } & kondisi & karakter \\
masyarakat & saat & ini, & pemerintah \\
mengambil & inisatif & untuk
\end{tabular} mengarusutamakan pembangunan karakter bangsa. Hal itu tercermin dalam Rencana Pembangunan Jangka Panjang Nasional Tahun 2005-2025, yang menempatkan pendidikan karakter sebagai misi pertama dari delapan misi guna mewujudkan visi pembangunan nasional. Dalam berbagai kesempatan Presiden Republik Indonesia juga mengemukakan pentingnya pembangunan watak (character building), karena kita ingin membangun manusia yang berakhlak, berbudi pekerti dan berperilaku baik.

\section{Pendidikan Karakter Bangsa Melalui Pendidikan}

Pendidikan karakter adalah usaha sadar dan terencana untuk mewujudkan suasana serta proses pemberdayaan potensi dan pembudayaan peserta didik guna membangun karakter pribadi dan/atau kelompok yang unik-baik sebagai warga negara. Hal itu diharapkan mampu memberikan kontribusi optimal dalam mewujudkan masyarakat yang berketuhanan yang Maha Esa, berkemanusiaan yang adil dan beradab, berjiwa persatuan Indonesia, berjiwa kerakyatan yang dipimpin oleh hikmat kebijaksanaan dalam permusyawaratan/ perwakilan, berkeadilan sosial bagi seluruh rakyat Indonesia. 
Pendidikan merupakan tulang punggung strategi pembentukan karakter bangsa. Strategi pembangunan karakter bangsa melalui pendidikan dapat dilakukan dengan pendidikan, pembelajaran, dan fasilitasi. Dalam konteks makro, penyelenggaraan pendidikan karakter mencakup keseluruhan kegiatan perencanaan, pengorganisasian, pelaksanaan, dan pengendalian mutu yang melibatkan seluruh unit utama di lingkungan pemangku kepentingan pendidikan nasional.

Peran pendidikan sangat strategis karena merupakan pembangun integrasi nasional yang kuat. Selain dipengaruhi faktor politik dan ekonomi, pendidikan juga dipengaruhi faktor sosial budaya, khususnya dalam aspek integrasi dan ketahanan sosial.

Disadari bahwa pembangunan karakter bangsa dihadapkan pada berbagai masalah yang sangat kompleks. Perkembangan masyarakat yang sangat dinamis sebagai akibat dari globalisasi dan pesatnya kemajuan teknologi komunikasi dan informasi tentu merupakan masalah tersendiri dalam kehidupan masyarakat. Globalisasi dan hubungan antarbangsa sangat berpengaruh pada aspek ekonomi (perdagangan global) yang mengakibatkan berkurang atau bertambahnya jumlah kemiskinan dan pengangguran. Pada aspek sosial dan budaya, globalisasi mempengaruhi nilainilai solidaritas sosial seperti sikap individualistik, materialistik, hedonistik yang seperti virus akan berimplikasi terhadap tatanan budaya masyarakat Indonesia sebagai warisan budaya bangsa seperti memudarnya rasa kebersamaan, gotong royong, melemahnya toleransi antarumat beragama, menipisnya solidaritas terhadap sesama, dan itu semua pada akhirnya akan berdampak pada berkurangnya rasa nasionalisme sebagai warga negara Indonesia. Akan tetapi, dengan menempatkan strategi pendidikan sebagai modal utama menghalangi virus-virus penghancur tersebut, masa depan bangsa ini dapat diselamatkan.

Secara makro pengembangan karakter dibagi dalam tiga tahap, yakni perencanaan, pelaksanaan, dan evaluasi hasil. Pada tahap perencanaan dikembangkan perangkat karakter yang digali, dikristalisasikan, dan dirumuskan dengan menggunakan berbagai sumber, antara lain pertimbangan (1) filosofis: Pancasila, UUD 1945, dan UU N0.20 Tahun 2003 beserta ketentuan perundang-undangan turunannya; (2) teoretis: teori tentang otak, psikologis, pendidikan, nilai dan moral, serta sosial-kultural; (3) empiris: berupa pengalaman dan praktik terbaik, antara lain tokoh-tokoh, satuan pendidikan unggulan, pesantren, kelompok kultural, dll.

$$
\text { Pada tahap implementasi }
$$
dikembangkan pengalaman belajar dan proses pembelajaran yang bermuara pada pembentukan karakter dalam diri peserta didik. Proses ini dilaksanakan melalui proses pemberdayaan dan pembudayaan sebagaimana digariskan sebagai salah satu prinsip penyelenggaraan pendidikan nasional. Proses ini berlangsung dalam tiga pilar pendidikan yakni dalam satuan pendidikan, keluarga, dan masyarakat. Dalam masing-masing pilar pendidikan akan ada dua jenis pengalaman belajar yang dibangun melalui dua pendekatan yakni intervensi dan habituasi. Dalam intervensi dikembangkan suasana interaksi belajar dan pembelajaran yang sengaja dirancang untuk mencapai tujuan pembentulkan karakter dengan menerapkan kegiatan yang terstruktur. Agar proses pembelajaran tersebut berhasil guna, peran guru sebagai sosok panutan sangat penting dan menentukan. Sementara itu dalam habituasi diciptakan situasi dan kondisi dan penguatan yang memungkinkan peserta didik pada satuan pendidikannya, di rumahnya, di lingkungan masyarakatnya membiasakan diri berperilaku sesuai nilai dan menjadi 
karakter yang telah diinternalisasi dan dipersonalisasi dari dan melalui proses intervensi. Proses pembudayaan dan pemberdayaan yang mencakup pemberian contoh, pembelajaran, pembiasaan, dan penguatan harus dikembangkan secara sistemik, holistik, dan dinamis.

Pelaksanaan pendidikan karakter dalam konteks makro kehidupan berbangsa dan bernegara Indonesia, merupakan komitmen seluruh sektor kehidupan, bukan hanya sektor pendidikan nasional. Keterlibatan aktif dari sektor-sektor pemerintahan lainnya, khususnya sektor keagamaan, kesejahteraan, pemerintahan, komunikasi dan informasi, kesehatan, hukum dan hak asasi manusia, serta pemuda dan olahraga juga sangat dimungkinkan.

Pada tahap evaluasi hasil, dilakukan asesmen program untuk perbaikan berkelanjutan yang dirancang dan dilaksanakan untuk mendeteksi aktualisasi karakter dalam diri peserta didik sebagai indikator bahwa proses pembudayaan dan pemberdayaan karakter itu berhasil dengan baik, menghasilkan sikap yang kuat, dan pikiran yang argumentatif.

Pada konteks makro, program pendidikan karakter bangsa dapat digambarkan sebagai berikut.

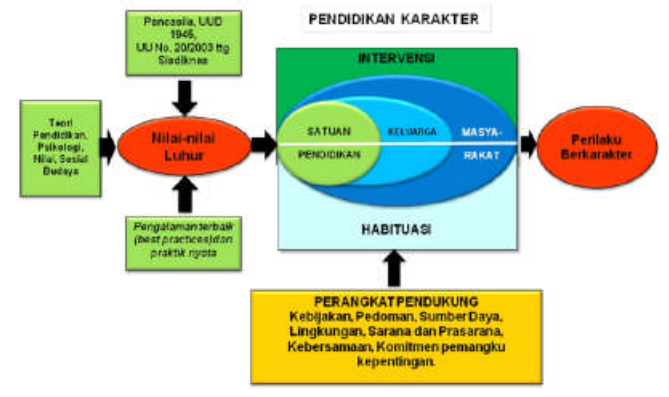

Gambar 1

Konteks Makro Pendidikan Karakter

Pendidikan karakter dalam konteks mikro, berpusat pada satuan pendidikan secara holistik. Satuan pendidikan merupakan sektor utama yang secara optimal memanfaatkan dan memberdayakan semua lingkungan belajar yang ada untuk menginisiasi, memperbaiki, menguatkan, dan menyempurnakan secara terus-menerus proses pendidikan karakter di satuan pendidikan. Pendidikanlah yang akan melakukan upaya sungguh-sungguh dan senantiasa menjadi garda depan dalam upaya pembentukan karakter manusia Indonesia yang sesungguhnya. Pengembangan karakter dibagi dalam empat pilar, yakni kegiatan belajarmengajar di kelas, kegiatan keseharian dalam bentuk pengembangan budaya satuan pendidikan; kegiatan kokurikuler dan/atau ekstra kurikuler, serta kegiatan keseharian di rumah dan masyarakat.

Pendidikan karakter dalam kegiatan belajar-mengajar di kelas, dilaksanakan dengan menggunakan pendekatan terintegrasi dalam semua mata pelajaran. Khusus, untuk materi Pendidikan Agama dan Pendidikan Kewarganegaraan - karena memang misinya adalah mengembangkan nilai dan sikap - pengembangan karakter harus menjadi fokus utama yang dapat menggunakan berbagai strategi/metode pendidikan karakter. Untuk kedua mata pelajaran tersebut, karakter dikembangkan sebagai dampak pembelajaran dan juga dampak pengiring. Sementara itu mata pelajaran lainnya, yang secara formal memiliki misi utama selain pengembangan karakter, wajib mengembangkan rancangan pembelajaran pendidikan karakter yang diintegrasikan kedalam substansi/kegiatan mata pelajaran sehingga memiliki dampak pengiring bagi berkembangnya karakter dalam diri peserta didik.

Lingkungan satuan pendidikan perlu dikondisikan agar lingkungan fisik dan sosial-kultural satuan pendidikan memungkinkan para peserta didik bersama dengan warga satuan pendidikan lainnya terbiasa membangun kegiatan keseharian di satuan pendidikan yang mencerminkan perwujudan karakter yang dituju. Pola ini ditempuh dengan melakukan pembiasaan dengan 
pembudayaan aspek-aspek karakter dalam kehidupan keseharian di sekolah dengan pendidik sebagai teladan.

Dalam kegiatan ko-kurikuler (kegiatan belajar di luar kelas yang terkait langsung pada materi suatu mata pelajaran) atau kegiatan ekstra kurikuler (kegiatan satuan pendidikan yang bersifat umum dan tidak terkait langsung pada suatu mata pelajaran, seperti kegiatan Kepramukaan, Dokter Kecil, Palang Merah Remaja, Pecinta Alam, Liga Pendidikan Indonesia, dll.) perlu dikembangkan proses pembiasaan dan penguatan dalam rangka pengembangan karakter.

Kegiatan ekstrakurikuler dapat diselenggarakan melalui kegiatan olahraga dan seni dalam bentuk pembelajaran, pelatihan, kompetisi atau festival. Berbagai kegiatan olahraga dan seni tersebut diorientasikan terutama untuk penanaman dan pembentukan sikap, perilaku, dan kepribadian para pelaku olahraga atau seni agar menjadi manusia Indonesia berkarakter. Kegiatan ekstrakurikuler yang diselenggarakan oleh gerakan pramuka dimaksudkan untuk mempersiapkan generasi muda sebagai calon pemimpin bangsa yang memiliki watak, kepribadian, dan akhlak mulia serta keterampilan hidup prima.

Di lingkungan keluarga dan masyarakat diupayakan agar terjadi proses penguatan dari orang tua/wali serta tokoh-tokoh masyarakat terhadap perilaku berkarakter mulia yang dikembangkan di satuan pendidikan sehingga menjadi kegiatan keseharian di rumah dan di lingkungan masyarakat masing-masing. Hal ini dapat dilakukan lewat komite sekolah, pertemuan wali murid, kunjungan/kegiatan wali murid yang berhubungan dengan kumpulan kegiatan sekolah dan keluarga yang bertujuan menyamakan langkah dalam membangun karakter di sekolah, di rumah, dan di masyarakat. Program pendidikan karakter pada konteks mikro dapat dilihat pada gambar 2.

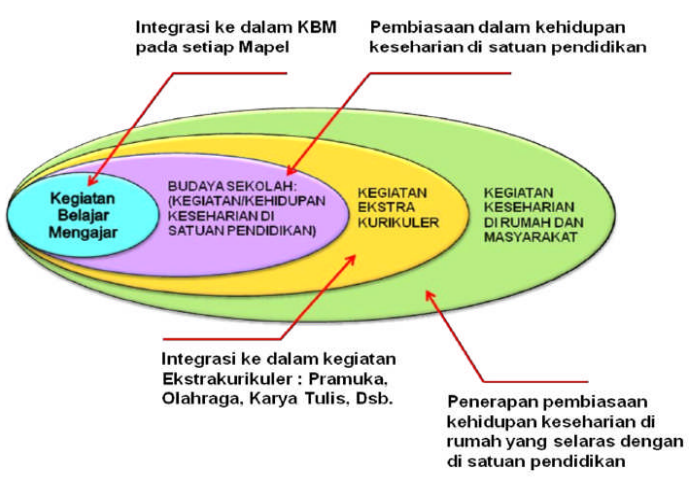

Gambar 2:

Konteks Mikro Pendidikan Karakter

Dengan prinsip yang sama, pendidikan karakter dapat dilakukan pada jalur pendidikan nonformal yang diselenggarakan oleh masyarakat, misalnya kursus keterampilan, kursus kepemudaan, bimbingan belajar, pelatihan-pelatihan singkat, baik yang diselenggarakan oleh pemerintah maupun organisasi massa. Demikian pula pendidikan karakter dapat dilakukan pada kegiatan kemasyarakatan lainnya, seperti kegiatan karang taruna, keagamaan, olahraga, kesenian, sosial, atau kegiatan pelatihan penanggulangan bencana alam.

Pendidikan nonformal yang dilaksanakan pada lingkup dunia usaha berbentuk pendidikan dan pelatihan calon pegawai, pelatihan kewirausahaan, pelatihan kepemimpinan, dan pelatihan keterampilan profesi. Pada lingkup masyarakat politik dilakukan bentuk pelatihan dan kaderasisasi partai, pelatihan kepemimpinan, pelatihan etika politik dan pembudayaan politik. Sedangkan pada lingkup media masa, pendidikan nonformal berupa pelatihan dasar komunikasi, pelatihan kode etik jurnalistik, dan pemahaman profesi jurnalis dan pelati han transaksi elektronik.

Pendidikan karakter pada kegiatan pendidikan dan latihan nonformal serta kegiatan kemasyarakatan tersebut dapat diarahkan untuk menanamkan kepedulian sosial, jiwa patriotik, kejujuran, dan kerukunan berkehidupan dalam masyarakat serta untuk mempersiapkan generasi muda 
sebagai calon pemimpin bangsa yang memiliki watak, kepribadian, dan akhlak mulia. Pendidikan karakter pada pendidikan nonformal dilaksanakan dengan pendekatan holistik dan terintegrasi pada setiap aspek pekerjaan atau kegiatan dalam kehidupan sehari-hari.

Strategi pembangunan karakter bangsa melalui program pendidikan memerlukan dukungan penuh dari pemerintah yang dalam hal ini berada di jajaran Kementerian Pendidikan Nasional. Oleh karena itu, fasilitasi yang perlu didukung berupa hal-hal sebagai berikut.

1. Pengembangan kerangka dasar dan perangkat kurikulum; inovasi pembelajaran dan pembudayaan karakter; standardisasi perangkat dan proses penilaian; kerangka dan standardisasi media pembelajaran yang dilakukan secara sinergis oleh pusatpusat di lingkungan Badan Penelitian dan Pengembangan Pendidikan Nasional.

2. Pengembangan satuan pendidikan yang memiliki budaya kondusif bagi pembangunan karakter dalam berbagai modus dan konteks pendidikan usia dini, pendidikan dasar dan menengah, serta pendidikan tinggi dilakukan secara sistemik oleh semua direktorat terkait di lingkungan Kementerian Pendidikan Nasional.

3. Pengembangan kelembagaan dan program pendidikan nonformal dan informal dalam rangka pendidikan karakter melalui berbagai modus dan konteks dilakukan secara sistemik oleh semua direktorat terkait di lingkungan Direktorat Jenderal Pendidikan Anak Usia Dini, Nonformal dan Informal.

4. Pengembangan dan penyegaran kompetensi pendidik dan tenaga kependidikan, baik di jenjang pendidikan usia dini, dasar, menengah maupun pendidikan tinggi yang relevan dengan pendidikan karakter dalam berbagai modus dan konteks dilakukan secara sistemik oleh semua direktorat terkait.

5. Pengembangan karakter peserta didik di perguruan tinggi melalui penguatan standar isi dan proses, serta kompetensi pendidiknya untuk kelompok Mata kuliah Pengembangan Kepribadian (MPK) dan Matakuliah Berkehidupan Bermasyarakat (MBB); penelitian dan pengembangan pendidikan karakter; pembinaan lembaga pendidikan tenaga kependidikan;

6. pengembangan dan penguatan jaringan informasi profesional pembangunan karakter dilakukan secara sistemik oleh semua direktorat terkait.

\section{STRATEGI KARAKTER BANGSA}

Pada dasarnya, kunci akhir sebuah strategi ada pada kerjasama dan koordinasi. Berbagai kerjasama dan kordinasi dapat dilakukan antarwarga negara, antarkelompok, antarlembaga, antardaerah, dan bahkan antarnegara. Ada beberapa cara yang dapat menjadikan kerjasama dapat berjalan dengan baik dan mencapai tujuan yang telah disepakati. Hal itu dapat dimulai dengan saling terbuka, saling mengerti, dan saling menghargai. Setelah kerjasama dapat dilakukan, maka langkah selanjutnya adalah koordinasi dan evaluasi. Pemerintah Republik Indonesia pada tahun 2010 mengeluarkan Kebijakan Nasional Pembangunan Karakter Bangsa Tahun 2010-2025. Adapun bentuk koordinasi yang dapat dilakukan antara lain:

1. koordinasi perencanaan kegiatan pendidikan karakter secara dinamis dari jenjang pendidikan usia dini, dasar, menengah, hingga pendidikan tinggi sesuai konteks kebutuhan dan perubahan zaman;

2. koordinasi dengan lembaga yang mengembangkan karakter bangsa melalui nilai budaya dan karya 
budaya;

3. koordinasi kegiatan satuan pendidikan dengan lembaga pendidikan di alam terbuka, antara lain gerakan Pramuka, dalam hal penerapan silabi pendidikan karakter;

4. koordinasi lembaga, agen, dan pemerhati yang saling terkait dengan pendidikan dan pengembangan karakter bangsa;

5. koordinasi secara teknikal dengan lembaga yang mengembangkan kompetensi teknologi informasi dan komunikasi, multimedia dalam pembuatan materi interaktif pendidikan karakter;

6. Koordinasi dengan lembaga yang mengembangkan kompetensi jasmani (bidang olahraga) dalam perencanaan pendidikan karakter bidang kompetensi olahraga;

7. Koordinasi dengan lembaga yang mengembangkan kompetensi bidang psikologi dan komunikasi dalam perencanaan model proses pembelajaran pendidikan karakter sesuai penciri warga negara agar mampu mengadaptasikan dirinya dalam pluralitas karakter di lingkungan global.

\section{SIMPULAN}

Pendidikan karakter merupakan roh yang mampu memberikan kehidupan dalam dunia pendidikan. Oleh karena itu, dalam mempercepat terlaksananya kebijakan nasional maka dibutuhkan sebuah kebijakan otonomi daerah sehingga daerah mampu berkreasi dalam meningkatkan pendidikan disetiap daerahnya. Adapun strategi yang dilakukan dalam upaya mempercepat kebijakan tersebut adalah dengan dimulai dengan saling terbuka, saling mengerti, dan saling menghargai. Setelah kerjasama dapat dilakukan, maka langkah selanjutnya adalah koordinasi dan evaluasi.

\section{DAFTAR PUSTAKA}

Masnur Muslich, 2011. Pendidikan Karakter, Menjawab Tantangan Krisis Multidimensional, Cet.2.Jakarta : Bumi Aksara.

Pemerintah Republik Indonesia. 2010. Kebijakan Nasional Pembangunan Karakter Bangsa Tahun 2010-2025.

Undang-Undang Dasar Rebulik Indonesia Tahun 1945.

Undang- Undang No. 20 tahun 2003 tentang Sistem pendidikan nasional

Undang- Undang Nomor 32 Tahun 2004 tentang Pemerintahan

Tilaar, H.A.R. 2012, Perubahan Sosial dan Pendidikan, Jakarta: PT.Rineka Cipta. 